\title{
The EU Training Network for Resource Recovery through Enhanced Landfill Mining-A Review
}

\author{
Daniel Vollprecht ${ }^{1, *(\mathbb{C},}$, Lieven Machiels ${ }^{2}$ and Peter Tom Jones ${ }^{3}(\mathbb{D}$ \\ 1 Chair of Waste Processing Technology and Waste Management, Montanuniversität Leoben, 8700 Leoben, \\ Austria \\ 2 Department of Chemistry, KU Leuven, 3001 Leuven, Belgium; lieven.machiels@kuleuven.be \\ 3 Department of Materials Engineering, KU Leuven, 3001 Leuven, Belgium; peter.jones@kuleuven.be \\ * Correspondence: daniel.vollprecht@unileoben.ac.at; Tel.: +43-3842-402-5110
}

check for

updates

Citation: Vollprecht, D.; Machiels, L.; Jones, P.T. The EU Training Network for Resource Recovery through Enhanced Landfill Mining-A

Review. Processes 2021, 9, 394.

https: / / doi.org/10.3390/ pr9020394

Received: 21 December 2020

Accepted: 18 February 2021

Published: 22 February 2021

Publisher's Note: MDPI stays neutral with regard to jurisdictional claims in published maps and institutional affiliations.

Copyright: (c) 2021 by the authors. Licensee MDPI, Basel, Switzerland. This article is an open access article distributed under the terms and conditions of the Creative Commons Attribution (CC BY) license (https:// creativecommons.org/licenses/by/ $4.0 /)$.

\begin{abstract}
The "European Union Training Network for Resource Recovery Through Enhanced Landfill Mining (NEW-MINE)" was a European research project conducted between 2016 and 2020 to investigate the exploration of and resource recovery from landfills as well as the processing of the excavated waste and the valorization of the obtained waste fractions using thermochemical processes. This project yielded more than 40 publications ranging from geophysics via mechanical process engineering to ceramics, which have not yet been discussed coherently in a review publication. This article summarizes and links the NEW-MINE publications and discusses their practical applicability in waste management systems. Within the NEW-MINE project in a first step concentrates of specific materials (e.g., metals, combustibles, inert materials) were produced which might be used as secondary raw materials. In a second step, recycled products (e.g., inorganic polymers, functional glass-ceramics) were produced from these concentrates at the lab scale. However, even if secondary raw materials or recycled products could be produced at a large scale, it remains unclear if they can compete with primary raw materials or products from primary raw materials. Given the ambitions of transition towards a more circular economy, economic incentives are required to make secondary raw materials or recycled products from enhanced landfill mining (ELFM) competitive in the market.
\end{abstract}

Keywords: enhanced landfill mining; NEW-MINE; waste treatment

\section{Introduction}

Although landfill mining, "the process for extracting minerals or other solid natural resources from waste materials that have previously been disposed of by burying them in the ground" [1], has been investigated since 1953 [2], the interest in this topic only really started in the 1980s in the USA [3] and the 1990s in Europe [4]. The main reasons for Landfill Mining towards at the end of the 20th century comprised landfill remediation and landfill volume recovery [5]. Between 2017 and 2015, several national (research) projects such as the "Closing the Circle" project (Flanders/Belgium) [6], the LAMIS project (Austria) [7-10], the MINERVE project (Wallonia/Belgium) [11] and the TönsLM project (Germany) [12] were conducted, which focused more on material and energy recovery. These projects covered different process steps ranging from geophysical exploration via exploration to dry and wet mechanical processing.

In summary, these studies demonstrated that using state-of-the-art technologies can yield concentrates of metals, inorganic-nonmetallic materials and combustibles. The metal concentrates can already be sold at the market, since standard pyrometallurgical recycling routes exist, which makes this fraction a key economic driver for landfill mining [13]. However, the inorganic-nonmetallic and combustible fractions are more challenging, while the remaining fine fraction represents the final sink for contaminants [14] that have to be removed from the circular economy [15]. In detail, recycling of inorganic-nonmetallic materials even from fresh construction and demolition waste is mainly as aggregate [16], 
which is a low-value application that is, furthermore, associated with a quality decrease due to the negative impact on the attached cement paste on concrete properties [17]. Similarly, energy recovery from calorific fractions of the waste may either occur by classical waste incineration processes [18] or after mechanical processing to refuse derived fuel (RDF) in co-incineration plants [19]. Nevertheless, even in the latter case the waste supplier has to pay for the material instead of obtaining revenues. Finally, regarding the fine fractions it has to be mentioned that $78 \%$ of excavated soils, most of them not contaminated, are landfilled in Austria [20] due to low landfilling costs and low material values. Therefore, it seems unlikely that contaminated soil-like materials from landfills would be recycled.

For these reasons the question arose if innovative technology might be an option to increase the economic feasibility of landfill mining projects. Consequently, in 2013 the term "enhanced landfill mining (ELFM)" was defined as "the safe conditioning, excavation and integrated valorization of (historic and/or future) landfilled waste streams as both materials (waste-to-material, WtM) and energy (waste-to-energy, $\mathrm{WtE}$ ), using innovative transformation technologies and respecting the most stringent social and ecological criteria" [6]. To investigate the potential of such "innovative transformation technologies" and to cluster the existing European expertise in the field of landfill mining, the European Enhanced Landfill Mining Consortium (EURELCO) was founded in 2014 [21]. From this consortium the "EU Training Network for Resource Recovery through Enhanced Landfill Mining (NEW-MINE)" was developed and received funding from the European Union in 2016. For a period of four years, 15 early stage researchers (ESRs) investigated the exploration of and resource recovery from landfills as well as the processing of the excavated waste and the valorization of the obtained waste fractions using thermochemical processes (Figure 1).

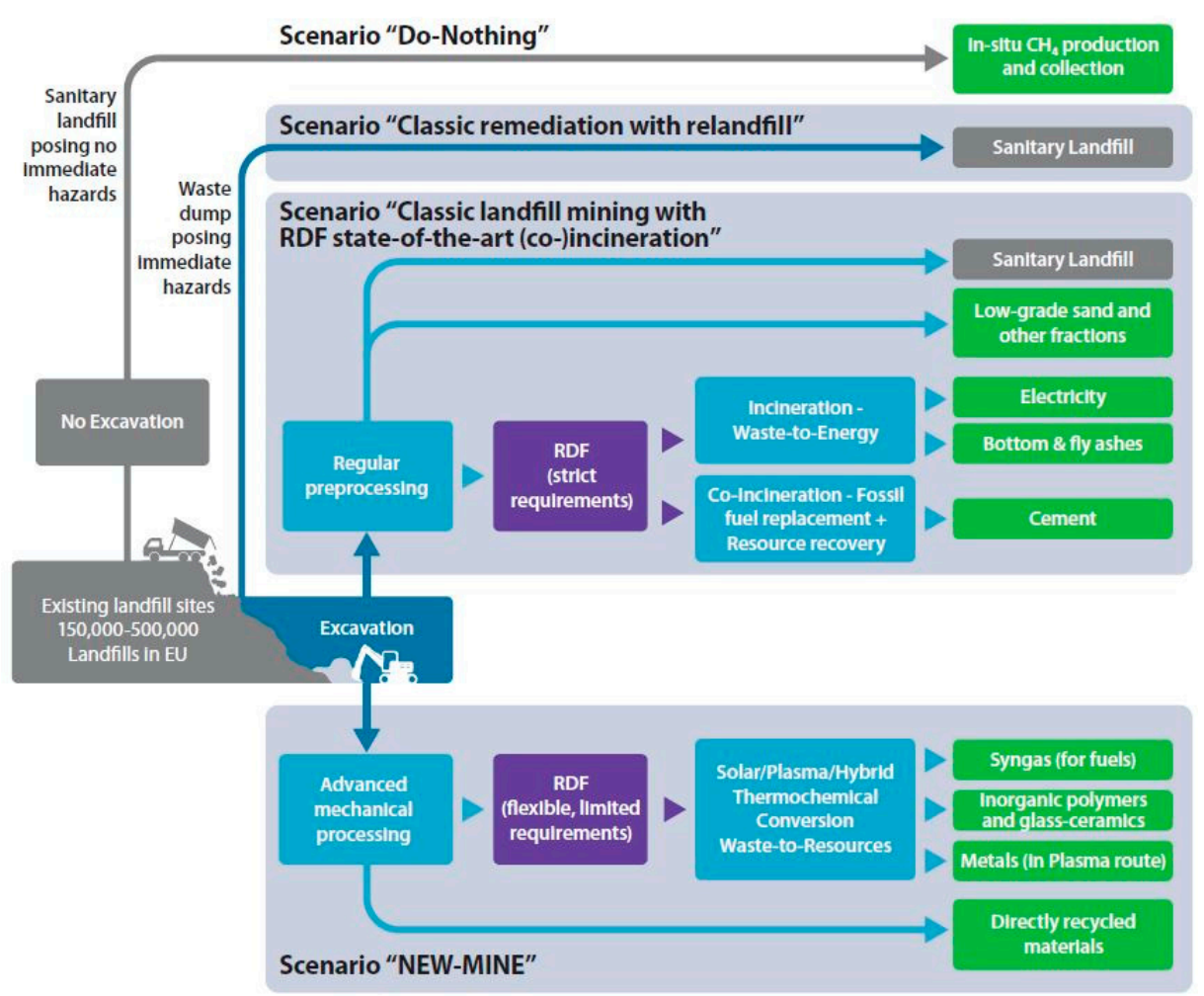

Figure 1. Approach of the NEW-MINE project (www.new-mine.eu accessed on 16 November 2020).

The NEW-MINE project yielded a significant output of scientific publications, ranging from geophysics via mechanical process engineering to ceramics. Although there is already a review article that links the first NEW-MINE results with previous investigations [22], there is no comprehensive review assessing the entire research output of NEW-MINE with 
respect to its practical applicability in waste management systems, which is the aim of this review article.

This article is structured in the following way: Firstly, the methods for literature review and discussion of the project results are given. Secondly, the project results are summarized referring to the individual publications. In this context also the state-of-theart before the project and the publications referring to the NEW-MINE publications are shortly summarized. Thirdly, in the Discussion section, the practical applicability of the NEW-MINE results in waste management systems is discussed. Finally, a summary of the project results and the challenges regarding their practical application is given.

\section{Materials and Methods}

Based on the publications listed on the NEW-MINE website (www.new-mine.eu accessed on 16 November 2020), additional publications of the authors were identified using Google Scholar and searching for the names of the NEW-MINE researchers. In a second step papers citing the NEW-MINE publications were identified and set into the context of NEW-MINE. The focus was on peer-reviewed publications, but certain conference proceedings were selected in those cases when the contained information was not found in a peer-reviewed article. Additionally, the search term "NEW-MINE" was used to find publications referring to this project. In the Google Scholar searches between dozens and few hundred articles appeared which were checked for consistency to the review topic. Publications by authors with similar names who were obviously other persons than the NEW-MINE researchers were excluded as well as publications referring to "new mines", but not to the NEW-MINE project. The entire literature research was conducted in November and December 2020. Finally, the results of the NEW-MINE project were checked for practical applicability based on the experience of the authors in waste management and on personal communications with colleagues over the last years. In this context, some theoretical reflections on resource classification and varying terminology in interdisciplinary research were added.

\section{Results}

3.1. Innovative Landfill Exploration $\mathcal{E}$ Mechanical Processing

3.1.1. Landfill Exploration

Landfills have been investigated long before the NEW-MINE project with respect to environmental problems arising from the landfilled waste [23-25]. With respect to the recovery of resources from landfills, the task for geophysical exploration is different: The landfill as a potential anthropogenic deposit shall be explored with respect to the quality, quantity and "bonitaet" (=geological factors influencing the mining) [26] of the contained secondary raw materials [27]. In contrast to pollutant-related exploration tasks, the resource-related exploration task aims not for the identification of individual objects or leakages but for the estimation of the average material composition. Before the onset of the NEW-MINE project only few studies focused on these kinds of exploration, e.g., for a distinction between landfilled foundry sands and iron-rich materials using magnetic methods [28]. Parallel to the NEW-MINE project, but not referring to it, another research group distinguished between metal enrichments and plastic enrichments in a landfill using a combination of electromagnetic and magnetic methods [29].

The publications within the NEW-MINE project include both applied studies focusing on the exploration of landfills with respect to the material composition and fundamental studies focusing on data processing of geophysical sensors.

The first applied study [30] investigated the suitability of electromagnetic induction measurements and ground penetrating radar to characterize the geometry and electric properties of waste layers. It was appreciated by scientists of two other EU project on ELFM, the SMARTGROUND project who cited it with respect to electromagnetic measurements in their study on ELFM in the UK [31], and the RAWFILL project who cited it with respect to geophysical exploration in general [32]. The second applied study [33] used magnetic total- 
field measurements to estimate the bulk magnetic susceptibility of the Hollabrunn landfill, Austria, by inverse modelling and validated the resulting susceptibility by manual sorting of drill-core samples. In parallel, the magnetic susceptibility of reference materials was determined by laboratory analyses and the resulting bulk susceptibility of the landfilled waste mixture was computed using a weighted mean. The differences between the bulk susceptibility derived from inverse modelling of the field data ( 0.06 to $0.11 \mathrm{SI}$ ) and the values obtained from computing from the values from the reference materials ( 0.01 to 0.05 SI) highlight the challenges to determine the iron content in landfills from magnetic data. This publication has not yet been cited, although two publications released in 2020 have addressed magnetic exploration in the context of landfill mining [34,35].

Consistent with the overall character of the NEW-MINE project and the requirements of the Marie Skłodowska Curie Actions, the share of fundamental research was dominant which is also reflected in the higher number of publications regarding the basic aspects of geophysical exploration. For example, a probabilistic inversion of electromagnetic data using the so-called Kalman ensemble generator, was introduced [36]. This approach has already been already cited twice by other authors $[37,38]$ and was further extended to a joint inversion of direct current resistivity and small-loop electromagnetic data [39], which was published in a mathematical journal, Algorithms, highlighting the interdisciplinarity of the NEW-MINE project. Finally, offset parameters were incorporated into the probabilistic inversion framework to estimate systematic errors in electromagnetic measurements [40].

In summary, the role of geophysics in post-NEW-MINE projects (e.g., RAWFILL) is higher than in pre-NEW-MINE projects (e.g., TönsLM), and post-NEW-MINE projects refer to the results of NEW-MINE.

\subsubsection{Mechanical Processing}

Mechanical processing of landfilled waste was the main focus in pre-NEW-MINE projects with dry methods being investigated in the LAMIS project [7] and wet methods in the TönsLM project [12].

Based on a comprehensive study on state-of-the-art processing of excavated waste from the Halbenrain landfill, Austria, using an existing mechanical-biological treatment (MBT) plant [41], a novel processing concept using a ballistic separator as first processing step for untreated excavated landfilled waste was developed and tested at the Mont-SaintGuibert landfill, Belgium [42]. The NEW-MINE approach to use state-of-the-art MBT was addressed outside NEW-MINE in the context of the problematic character of the fine fraction [43], its biological treatment to increase the value of the fine fraction [44], and regarding landfill mining in general [45].

A second key innovation in this field reached by NEW-MINE was the demonstration of the feasibility of near-infrared (NIR) sorting for the beneficiation of heavy fractions from dry-mechanical processing [46]. The authors could enrich the inert materials in these fractions from values between 85.6 to $98.8 \mathrm{wt} \%$ in the input to a range between 97.7 and $99.6 \mathrm{wt} \%$ in the output, by ejecting the plastics: this represents an important step towards a possible recycling of the inert fraction. Another finding, i.e., the impact of attached defilements on sorting performance, was subsequently considered in Austria's largest waste management project, ReWaste 4.0 [47]. The applicability of results from mechanical processing of ELFM materials to "fresh" waste highlights the relevance of NEW-MINE results in this field. Within NEW-MINE, the influence of surface roughness and surface moisture of plastics on NIR sorting was investigated [48], and the findings were used outside NEW-MINE for material flow characterization in sensor-based sorting systems using an instrumented particle [49] and for a study of the influence of material alterations and machine impairment [50]. NEW-MINE learnings on the effects of throughput rate and input composition on sensor-based sorting [51] were subsequently used within the above mentioned ReWaste 4.0 project $[47,52]$.

Finally, the challenge of the fine fraction, which has been identified in pre-NEW-MINE projects, e.g., in the LAMIS project [53], was firstly summarized in two review publica- 
tions [54,55]. A post-NEW-MINE study on contaminants in landfills [56], despite using a misleading soil definition [57], added further information on this topic. Other publications $[44,58]$ also addressed the observation that the fine fraction makes up the majority of the landfilled material, but used correct terminology. Further post-NEW-MINE studies on leachate characteristics [59] and composition of the fine fraction [60] added further information to these fields. The need to further process the fine fraction to minimize re-landfilling was mentioned by a publication on geophysical exploration of landfills [61]. The problem stated within NEW-MINE that currently no valorization options for the fine fraction exist because of the possibility of contamination of this fraction [43] was later considered by an Estonian [62] and by an Indian study [63]. The same statement was also extracted from the second review [55] but with the suggestion to tackle this problem by further processing [44]. In contrast, a Hungarian group extracted the contradicting statement that fine fractions can be considered as a relevant source of metals, calorific fractions, inert fractions and soil-like material recovery [64]. The explanation that the amount of the fine fraction increases over time due to humification processes was mentioned in an Indian study on the application of Fourier-transformed infrared spectroscopy for its characterization [65]. The need for a deeper understanding of the physico-chemical properties of the fine fractions including their distribution across the different grain size fractions was also applied to shredder fine fractions [66]. Within the field of landfill mining, the general observations regarding the fine fractions were considered by authors of the SMARTGROUND project [67].

Then, the fine fraction $<90 \mathrm{~mm}$ obtained by ballistic separation was characterized [68] and further separated into a light fraction, a heavy fraction, ferrous and non-ferrous metals and a fine fraction $<4.5 \mathrm{~mm}$ using windsifting, magnetic separation, eddy-current separation and screens [69]. The heavy fraction was investigated with respect to the utilization as construction material and the light fraction with respect to the use as refuse derived fuel (RDF) [70]. The fine fraction $<4.5 \mathrm{~mm}$ was further processed and characterized with respect to the relationship between mineralogy and leachability indicating the stable mineralogical bonding of many contaminants (e.g., $\mathrm{Pb}$ as metal and $\mathrm{Pb}-\mathrm{Ca}$ phosphate and $\mathrm{Zn}$ as Fe- $\mathrm{Zn}$ alloy, $\mathrm{ZnS}$ and $\mathrm{ZnSO}_{4}$ ) [71].

In summary, novel research results obtained within NEW-MINE, especially using sensor-based sorting, can be applied to areas beyond ELFM.

\subsection{Thermochemical Conversion and Solar Energy Storage}

\subsubsection{Thermochemical Conversion}

Most pre-NEW-MINE landfill mining projects covered the value chain from exploration via excavation and mechanical treatment to the production of concentrates of secondary raw materials, i.e., metals for pyrometallurgical recycling, mineral wastes for the production of construction materials and combustibles for energy recovery. These concentrates are still wastes (and not products) but state-of-the-art recyling and recovery routes do exist, which is why the actual recycling or recovery was not part of most of these projects. With respect to the combustibles these recovery routes include among others:

- Municipal solid waste incineration plants (MSWI plants)

- Refuse derived fuel power plants (RDF power plants)

- Cement works (co-incineration)

- Coal-fired power plants (co-incineration)

- Industrial power plants (co-incineration) [72].

Consequently, previous projects investigated the combustibles with respect to the (co-) incineration in existing facilities considering not only calorific properties but also the content of heavy metals [7] as these restrict the valorization options of RDF by coincineration [19]. For those cases in which the combustibles fulfil the requirements for coincineration in the cement industry, the inorganic constituents of the RDF are incorporated into the mineral phases of the clinker contributing to its desired hydraulic properties, which justifies to address the share of RDF used on a material level as "recycling index" [73]. In contrast, for those cases in which contaminant concentrations exceed limit values for 
RDF, energy recovery in MSWI plants is the state-of-the-art option. MSWI yields bottom ashes whose recycling is restricted by limit values for total concentrations and/or leachable concentrations of contaminants $[74,75]$. The chemical composition and leachability, as well as the element-specific limit values significantly vary between individual EU member states. Table 1 presents the ranges of concentrations relative to ranges of limit values for material used in road construction, showing that the total contents of $\mathrm{Cd}, \mathrm{Cu}, \mathrm{Cr}, \mathrm{Pb}$ and $\mathrm{Zn}$ and the leachable contents of $\mathrm{Pb}$ are most problematic.

Table 1. Ranges of total ( $\mathrm{mg} / \mathrm{kg}$ ) [76] and leachable (mg/L) [76,77] contents and respective limit values (CH, DK, SWE, FIN, FRA, AUT, D, NL, BEL for total and DK, ESP, SWE, FIN, FRA; AUT, GER; NED, BEL for leachable contents) for recycling of MSWI bottom ashes.

\begin{tabular}{ccc}
\hline Total Content & Concentrations & Limit Values \\
\hline $\mathrm{Cd}$ & $1-177$ & $0.2-10$ \\
$\mathrm{Cu}$ & $738-17620$ & $40-500$ \\
$\mathrm{Cr}$ & $115-852$ & $40-500$ \\
$\mathrm{Ni}$ & $38-850$ & $35-500$ \\
$\mathrm{~Pb}$ & $197-6441$ & $20-1250$ \\
$\mathrm{Zn}$ & $1142-9370$ & $120-1250$ \\
\hline Leachable Content & Concentrations & Limit Values \\
$\mathrm{Cl}$ & $259-416$ & $80-5000$ \\
$\mathrm{Cr}$ & 0.01 & $0.006-0.5$ \\
$\mathrm{Ni}$ & $<0.05$ & $0.01-0.35$ \\
$\mathrm{Sb}$ & $0.016-0.023$ & $0.006-0.2$ \\
$\mathrm{SO}$ & $15-106$ & $70-6500$ \\
$\mathrm{~Pb}$ & $1.8-6$ & $0.02-0.82$ \\
\hline
\end{tabular}

Following the pathway of classic incineration for those calorific fractions exceeding the threshold values for co-incineration would, therefore, result in the need to re-landfill significant proportions of the resulting bottom ashes. Disposal of MSWI bottom ash at increasing scarcity of landfill volume and the need for landfill aftercare for up to more than 100 years [78] is associated with significant costs, which will represent a massive financial and environmental burden for governments and the public in the future.

This is why within NEW-MINE, despite sharp criticism [79], gasification and pyrolysis were investigated as alternative thermochemical conversion processes within NEW-MINE with the background idea to use the produced syngas and to couple these processes to plasma technology to convert the resulting ashes directly into a vitreous slag, which might be favorable compared to MSWI bottom ashes with respect to mechanical and leaching properties. As it was not possible within the project to test plasma technology, vitreous slag from previous tests was used for further experiments, but also MSWI bottom ash was melted to obtain a similar slag.

Within NEW-MINE, the light fraction obtained by mechanical processing of excavated waste from the Mont-Saint-Guibert landfill was subjected to pyrolysis $\left(\mathrm{N}_{2}\right.$ atmosphere, 900 ${ }^{\circ} \mathrm{C}, 1 \mathrm{~h}$ ) and the resulting char was subjected to steam gasification using thermogravimetry analysis (TGA) to study the reaction kinetics [80]. This publication was cited as one of the few studies on gasification kinetics of MSW chars [81] and regarding the observed increase in activation of the char by gasification [82]. Furthermore, the study was cited with respect to the energy savings, low $\mathrm{NO}_{x}$ emissions and pollutant reduction of steam gasification compared to conventional thermochemical conversion technologies [83]. In a second study, a sample of the fine fraction $(<10 \mathrm{~mm})$ and two samples of combustibles (with different share of defilements) were used for a similar experimental setup [84]. The latter publication was cited in a review on co-incineration of organic waste and coal [85] and with respect to the higher production of $\mathrm{CO}$ and $\mathrm{CO}_{2}$ in pyrolysis when using finer waste fractions in a publication on the prediction of gaseous products from RDF pyrolysis [86]. Two further results originated from this NEW-MINE publication: (1) pyrolysis of landfilled 
waste yields less oil and gas than pyrolysis of fresh waste and (2) gasification of char from pyrolysis of landfilled waste yields waste fuel with a higher reactivity compared to the same process using fresh waste, which is explained by the catalytic effect of the metals present in landfilled waste [87]. Further studies citing this publication are on pyrolysis of pre-treated trommel fines [88]. In the third study on this topic, it was shown that steam co-gasification of landfilled waste with biochar increase $\mathrm{H}_{2}$ yields [89]. This publication was mentioned in a review article on waste-to-energy technologies [90] and with respect to the use of the syngas from gasification for ammonia synthesis [91].

The second issue addressed within NEW-MINE regarding gasification was the cracking of tars from the produced syngas which would restrict its utilization options. At first, a review on the state of the art regarding the role of plasma in syngas tar cracking [92] was published, which was cited outside of NEW-MINE by two other review articles [93,94] mentioning the efficiency, but also the short lifetime and high costs of this technology, as well as a novel warm gas tar cleaning processing called OLGA. In a next step, naphthalene was used as a model tar molecule and Corona plasma-aided thermal cracking was demonstrated successfully for its removal at $800{ }^{\circ} \mathrm{C}$ [95]. This study was cited with respect to tar generation and conversion kinetics [96], regarding the required high temperatures of $1100{ }^{\circ} \mathrm{C}$ which represent a disadvantage compared to catalytic reforming [97], and as an example for thermal tar cracking [98]. Finally, two CaO-rich catalysts doped with Sr were synthesized from mussel shells and successfully tested for tar cracking in the syngas [99].

Another NEW-MINE publication focused on further aspects of the pyrolysis process. Lab-scale pyrolysis tests at 400 to $700{ }^{\circ} \mathrm{C}$ with the above-mentioned light fraction of the Mont-Saint-Guibert landfill revealed the enrichment of polycyclic aromatic hydrocarbons (PAH) in the condensable pyrolysis products, highlighting the need to further treat this output fraction [100]. Although the main focus of thermochemical conversion technologies within NEW-MINE was on the treatment of the combustibles, thermal treatment $(400 / 450$ ${ }^{\circ} \mathrm{C}, 30 \mathrm{~min}$ ) was also used to assess the quality of the nonferrous metals obtained from mechanical processing of the excavated waste from Mont-Saint-Guibert landfill [101].

\subsubsection{Solar Energy Storage}

In contrast to waste incineration and co-incineration, which produce energy and even contribute to $3.7 \%$ of the German end energy consumption [72], gasification requires external energy. The use of energy from renewable sources for this purpose is environmentally favorable, but requires energy storage. Consequently, within NEW-MINE, MgO-stabilized $\mathrm{SrO}$ was synthesized and successfully tested for heat storage via the $\mathrm{SrO} / \mathrm{SrCO}_{3}$ cycle [102]. This research was considered outside NEW-MINE with respect to radiation propagation in a heat exchanger transforming solar radiation into high-temperature heat [103], thermochemical energy storage in the $\mathrm{CaO} / \mathrm{CaCO}_{3}$ [104] and $\mathrm{MnAl}_{2} \mathrm{O}_{4} / \mathrm{MnAl}_{2} \mathrm{O}_{4-x}$ [105] system and two reviews on thermochemical energy storage $[106,107]$. The most recent NEW-MINE publication in this field deals with thermochemical heat storage via the $\mathrm{CuO} / \mathrm{Cu}_{2} \mathrm{O}$ redox cycle and describes the synthesis of granules with a gravimetric energy storage density in the range of 470 to $615 \mathrm{~kJ} \mathrm{~kg}^{-1}$ [108].

In summary, NEW-MINE publications on thermochemical conversion and solar energy storage focused on the organic constituents of gasification chars and of oxide/carbonate systems for solar energy storage and created a novel state-of-the-art. However, the fate of inorganic pollutants during gasification was not addressed and the intended production of vitreous slags via plasma processing that might immobilize these pollutants was not realized in the project.

\subsection{Benefication of Products from Thermochemical Conversion}

3.3.1. Melting and Vitrification

Since the intended plasma gasification of ELFM materials was not realized within NEW-MINE, three groups of input materials were selected for further processing, i.e., (1) MSWI bottom ashes, (2) vitreous slag from plasma gasification ("Plasmastone") from 
a pre-NEW-MINE project and (3) synthetic vitreous slags mimicking the plasmastone composition. The aims of the beneficiation of these materials comprised the recovery of metals and the beneficiation of the nonmetallic fractions for specific applications in civil engineering beyond the state-of-the-art applications of MSWI bottom ashes as low-strength aggregates [109]. Thermal treatment of MSWI bottom ashes within NEW-MINE aimed for the recovery of metals and beneficiation of the mineral fraction. For this purpose, two heating technologies were investigated.

Firstly, a submerged arc furnace (SAF) and an electric resistance furnace (ERF) were used to melt MSWI bottom ash obtained from a Dutch MSWI plant at 1500 and $1400{ }^{\circ} \mathrm{C}$, respectively. These experiments yielded an $\mathrm{Cu}$-Fe alloy and a vitreous $\mathrm{CaO}-\mathrm{Al}_{2} \mathrm{O}_{3}-\mathrm{SiO}_{2}$ slag, which might be used for the production of glass ceramics or inorganic binders [110] and were linked to the application of SAF technology in other fields [111].

Secondly, microwave heating was used to study the dielectric properties from the above mentioned MSWI bottom ash from a Dutch MSWI plant and revealed that MSWI bottom ash absorbs microwaves with low losses until $320^{\circ} \mathrm{C}$ but above this temperature pyrolysis enhances the dielectric loss [112]. This study was cited with respect to microwave cladding, an emerging surface modification technique [113]. In a next step, flash microwave vitrification was realized at $2.45 \mathrm{GHz}$ within $1.5 \mathrm{~min}$. The advantage of this technology for vitrification is that the cooling rate is naturally so fast, due to the inherent cold environment, that no specific efforts are required for quenching [114].

\subsubsection{Alkali Activation}

The next group of studies within NEW-MINE dealt with the further benefication of vitrified MSWI bottom ashes. In one study, the vitrified bottom ash was subjected to alkali activation $\left(1 \mathrm{M} \mathrm{NaOH}\right.$ and $2.5 \mathrm{M} \mathrm{NaOH}$ and sinter crystallization $\left(800{ }^{\circ} \mathrm{C}\right.$ or 900 ${ }^{\circ} \mathrm{C}$ ), thereby yielding porous (70 vol\%) glass ceramics with a compressive strength of 3 $\mathrm{MPa}$, which might be used as an alternative to lightweight concrete [115]. Another group of studies addressed the production of inorganic polymers by alkali activation. Compared to geopolymers, which are the main subgroup of alkali activated materials, inorganic polymers differ with respect to their chemical composition.

A synthetic plasmastone analogue was used to study the impact of solid-to-liquid and $\mathrm{K}_{2} \mathrm{O} / \mathrm{SiO}_{2}$ ratio and the type of activation solution on the resulting inorganic polymers. Adjustment of these process parameters yielded inorganic parameters with a compressive strength of up to $119 \mathrm{MPa}$ [116]. This study was cited in a review article as an example to valorize vitrified MSWI bottom ash [117]. Based on these findings, strategies to increase the volumetric stability of inorganic polymers were developed [118]. This work was cited in the context of alternative cementitious materials for radioactive waste encapsulation, taking into account that strengthening of inorganic polymers was observed due to radiationinduced iron oxidation [119]. One approach to increase the volumetric stability is the addition of CaO-rich materials, which was demonstrated in another study [120].

\subsubsection{Sintering of Glass-Ceramics}

The last group of studies refers to the sintering of vitreous slags from plasma processing of MSW or from MSWI vitrification to glass ceramics, which might be used as building materials such as aggregates and panels. The most-cited publication of NEW-MINE [121] dealt with the production of porous glass ceramics from the vitreous slag obtained by plasma processing of MSW. It was demonstrated how increasing the firing temperature of glass ceramics can trap chromium in stable pyroxene group minerals and adding borosilicate glass can decrease the leaching of $\mathrm{Cr}$, Mo and $\mathrm{V}$ as boron acts as a network former. This paper was cited in publications on the preparation of glass-containing foams from geopolymers [122] and vitrified MSWI bottom ash [123] in which the formation of wollastonite and the freezing of the microstructural evolution were mentioned. Other papers cited this publication with respect to the recycling of glass waste into foam glass [124-129], porous waste glass for lead removal in wastewater treatment [130], lead stabilization through 
alkali activation and sintering of Pb-bearing sludge [131], utilization of waste glass for the production of sulphuric acid resistant concrete [132], mechanical and alkali activation of MSWI fly and bottom ashes for the production of low-range alkaline cement [133] and foam glass-ceramics [134], inorganic gel casting for manufacturing of boro-alumino-silicate glass foams [135], porous glass-ceramics derived from $\mathrm{MgO}-\mathrm{CuO}-\mathrm{TiO}_{2}-\mathrm{P}_{2} \mathrm{O}_{5}$ glasses [136], alkali activation of coal and biomass fly ashes [137], nickel-based catalysts for steam reforming of naphthalene utilizing MSW gasification slag as support [138], production of porous glass ceramics from titanium mine tailings and waste glass [139], porous bioactive glass microspheres [140], $\mathrm{Al}-\mathrm{SiO}_{2}$ composites [141], glass-ceramic foams from alkali-activated vitrified MSWI bottom ash and waste glasses [142]. Another study used vitrified MSWI bottom ash as input material to obtain similar porous glass ceramics [143] and was cited by some of the publications that also cited the first study.

In a next step, dense glass with good mechanical and environmental properties (low leaching due to stable incorporation of heavy metals in stable hedenbergite, wollastonite and iron oxides) were obtained from a mixture of "Plasmastone", recycled soda-lime glass and kaolin clay by cold pressing and fast heat treatment $\left(1000^{\circ} \mathrm{C}, 40^{\circ} \mathrm{C} / \mathrm{min}\right)$ [144]. This publication was referred to as a case study for the influence of crystallization time on glass ceramics [145].

The crucial linkage between mineralogy and technical and environmental performance was also investigated in a further study in which low temperatures $\left(800{ }^{\circ} \mathrm{C}\right)$ were sufficient to immobilize heavy metals in a stable matrix using spent borosilicate glasses and additional electromagnetic shielding functionalities were obtained by magnetite formation [146]. This approach was cited in a study on the substitution of feldspar by waste glass for porcelain production [147] and in a paper on cheap pore-generating agents for ceramics [148]. Finally, the promoting effect of firing in nitrogen atmosphere on the stabilization of pollutants and novel functionalities was investigated [149]; the paper was cited in studies on the recycling of iron-rich inorganic wastes into functional glass-ceramics [150] and on the production of glass ceramics from MSWI bottom ash and coal fly ash by melting and sintering [151].

In summary, the NEW-MINE publications on beneficiation of products of thermochemical conversion of (excavated) MSW, i.e., vitrified MSWI bottom ashes and vitreous slags of plasma gasification, yielded novel insights into the relation between (crystalline/vitreous) structure and (mechanical/leaching) properties of waste-derived glass ceramics and inorganic polymers. Although these specific approaches to address MSWI residues might not be realized in practical waste management, the underlying mechanisms are also relevant for the mobility of heavy metals in other mineral wastes and allow the eco-design of their properties and, consequently, enhanced recyclability.

\subsection{Multi-Criteria Assessment}

\subsubsection{Life Cycle Assessment}

Already before NEW-MINE, comprehensive methods for landfill mining projects have been developed. With respect to ecological and socio-economic criteria, this approach was based on utility analysis and then transferred into a utility-net present value chart [9]. In contrast, within NEW-MINE, for the ecological assessment life cycle assessment (LCA) was used, although it was not applied to landfill mining, but to the impact of sanitary landfills themselves [152]: this approach yields important information regarding the alternative to ELFM, i.e., state-of-the-art landfill aftercare. This LCA publication was cited with respect to the site selection for landfills $[153,154]$ and in a study which yielded the controversial statement that "recycling metals except gold had more negative environmental impacts than mining" [155]. Further citing studies deal with environmental impacts of combustion-based energy production [156], composting on closed landfill sites [157], bioreactor landfills [158], suppression of methane generation [159], modelling of landfill gas production [160], organic waste enrichment [161]. Within NEW-MINE, LCA was also applied to compare smelting of MSWI bottom ash with the state-of-the-art mineral process- 
ing approach and revealed that the energy demand for smelting processes overrules, with respect to global warming, the positive effect of secondary raw material production [162].

In summary, LCA demonstrated the environmental impact of all scenarios of landfill management. Landfill aftercare requires a high effort for gas and leachate treatment, while traditional landfill mining with MSWI yields mineral fractions of MSWI bottom ashes which cannot substitute for high-value primary raw materials due to the leaching of pollutants. In contrast ELFM, with the production of vitreous slags-either via plasma gasification of municipal solid waste (MSW) or via smelting of MSWI bottom ashes, yields more valuable secondary raw materials which are characterized by a lower leaching, but their production requires more energy.

\subsubsection{Techno-Economic Assessment}

Based on a comprehensive study on existing economic assessment methods [163] it has been suggested within NEW-MINE to follow learning-oriented approaches. Subsequently, an economic and environmental assessment of a possible ELFM project in Sweden has been conducted and revealed that none of the scenarios is economically profitable, but of all them result in net avoided emissions due to the recovery of metals [164]. In a next step, more than 500,000 landfill mining scenarios were evaluated with respect to their net present value and the influencing factors were identified via global sensitivity analysis. It was found that $80 \%$ of these scenarios show negative results and that revenues from avoided landfill management costs are more important than revenues from resource recovery [165]. This study was cited in a review paper on the impact of landfills on the environment [166] in a study on the environmental and economic assessment of ELFM in Tehran [167] and with respect to geophysical exploration of landfills [35].

In summary, NEW-MINE results confirm that ELFM is ecologically favorable, but economically not profitable, which demonstrates the need for an integrated ecological and economic assessment [9,35]. This means, that for those cases in which this integrated assessment shows a positive effect of ELFM, economic incentives would be required to make secondary raw materials or recycled products from ELFM competitive in the market.

\subsubsection{Sociological Assessment}

Before NEW-MINE, landfill mining was investigated mainly from technological, environmental and economic perspectives. However, it is well known that large infrastructure projects often fail due to public resistance [168]. Therefore, within NEW-MINE, also stakeholders' perspectives on ELFM were investigated [169] and stakeholder needs were identified [170]. The latter study was cited in a study on the characterization of excavated waste [171]. Finally, stakeholder archetypes for ELFM were defined: The Engaged Citizen, the Entrepreneur, the Technology Enthusiast, the Visionary and the Skeptic [172]. In summary, the importance of the involvement of stakeholders in ELFM has been demonstrated and fundamentals for corresponding strategies have been laid.

\section{Discussion}

\subsection{Disciplinarity and Interdisciplinarity}

Within the NEW-MINE project the entire process chain, from landfill exploration via excavation and mechanical processing to thermochemical conversion and beneficiation of conversion products, has been investigated. This broad scope constituted a unique feature of the NEW-MINE project and, correspondingly, many publications do not address the landfill mining itself, but waste treatment technologies, which may also be used for waste from other sources than landfills. Some publications, e.g., dealing with energy storage, are only loosely linked to landfill mining. This broad scope enabled the interdisciplinary collaboration of researchers, for example between geophysicists and waste scientists [33], waste scientists and polymer scientists [48], experts in mechanical and thermal waste treatment $[84,89,101]$ and in high and low temperature waste mineralogy $[121,144]$. However, the majority of the publications can be allocated to a single scientific discipline. With 
respect to the number of publications citing the NEW-MINE publications, no significant difference between disciplinary and interdisciplinary publications is visible. Although most disciplinary publications were cited by researchers from other disciplines (e.g., [165] by [35]), most of them were cited by colleagues from the authors' discipline.

Considering that the overall research question of the project was to investigate if innovative technologies increase the economic and environmental feasibility of landfill mining, more interdisciplinary cooperation would be required. For example, if the purity of an inert fraction obtained by sensor-based sorting is increased from 86 to $98 \%$ [46], what is then the impact on the economic, environmental and societal assessment of ELFM? This and several similar questions demonstrate the need for further interdisciplinary research in the field of ELFM for which NEW-MINE could have been an excellent starting point.

\subsection{Recycling Waste from Landfills}

Although a lot of reasons for landfill mining have been identified and excavation of landfills for environmental remediation has been practiced already for decades, it is the recovery of resources from landfills, which fostered the landfill mining projects in the last decade including the NEW-MINE project This is clearly indicated in the project's name, i.e., "EU Training Network for Resource Recovery Through Enhanced Landfill Mining". During the NEW-MINE project a lot of effort was devoted to treat the excavated waste by mechanical, thermochemical and chemical methods. The final aim of these treatments is to obtain either a secondary raw material, which may substitute for a primary raw material in an industrial process, or a product, which substitutes for a product with the same functionalities but is made from primary raw materials. Regarding the production of secondary raw materials, NEW-MINE demonstrated that e.g., the 2D fraction of ballistic separation can substitute for fossil fuels in co-incineration plants. In contrast, the use of the inert fraction as raw material for the production of concrete [70] and the use of the fine fraction as raw material for the production of compost soil [71] fails, due to the exceeded limit values for total and leachable contaminants.

Regarding the production of a product, it has been demonstrated that e.g., glassceramics [144] fulfil the mechanical and leaching requirements for building products. Apart from the problem that several countries, e.g., Austria, have also limit values for total contents, it has to be mentioned that these products have to compete with products with the same functionality but are made from primary raw materials. Consequently, comparative economic and environmental assessments are required to investigate the production costs and environmental impact of e.g., lightweight concrete made from primary raw materials (e.g., Airium ${ }^{\mathrm{TM}}$ ) and waste-derived glass-ceramics that compete for the same application. With respect to raw materials, the same applies: e.g., recycled aggregates compete with natural aggregates (with the problem of decreasing quality with increasing number of recycling cycles [173]), but also additional challenges occur: The RDF that can be produced by ballistic separation or windsifting has a negative value, i.e., the producer has to pay the cement plant to incinerate it. Therefore, within the Halbenrain case study in NEWMINE, the lightweight fraction, which could have been delivered to an RDF production plant was re-landfilled, as this was the cheaper option. The reason for this paradox is that combustible waste must not be landfilled in Austria and incineration is an expensive process, considering also the taxes that have to be paid. Therefore, co-incineration plants can demand negative prices for RDF, as it is still cheaper than incineration. Only for the specific case study of ELFM, re-landfilling of combustibles is allowed and represents the cheapest option.

In summary, even if secondary raw materials or recycled products can be produced from ELFM materials, it remains unclear if they can compete with primary raw materials or products from primary raw materials. First observations for Austria suggest that this may often not be the case. Given the ambitions of transition towards a more circular economy, economic incentives are required to make secondary raw materials or recycled products from ELFM competitive in the market. 


\subsection{Waste Management Meets Mining Economics}

Finally, as is already evident in the project name "NEW-MINE" in which terminology from mining economics ("resources") and waste management ("landfill") are used, it represents a good example to apply a figure illustrating the different terminologies from mining economics, waste management and process engineering [27] to MSW landfills and ELFM (Figure 2).

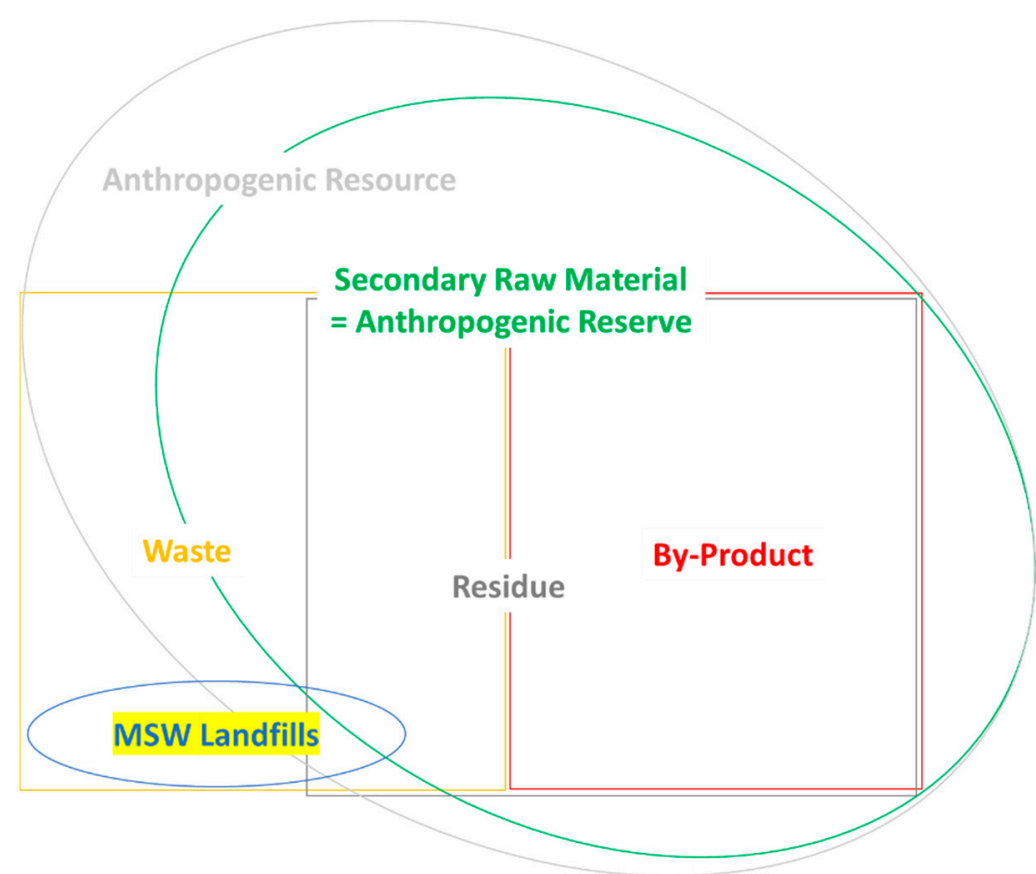

Figure 2. Location of MSW landfills in waste and resource terminology (Reprinted with permission from ref. [27]. Copyright 2020. Daniel Vollprecht).

Often, in the recycling business, the term "waste" is avoided due to its negative connotations. Instead, the terms "residue", "anthropogenic resource", "by-product" or "secondary raw material" are used, but they have a different meaning.

Waste is precisely defined in the European Waste Framework Directive [174] as "any substance or object which the holder discards or intends or is required to discard". Consequently, the material in an MSW landfill is waste, as the (former) holder discarded it. If the material is recycled, it reaches the end-of-waste at the moment when it substitutes for a primary raw material. Considering the technologies investigated within NEW-MINE, this means that the material remains a waste until the waste-derived glass ceramics or inorganic binders finally substitute for conventional construction ceramics or cement, respectively, and this only if they fulfil the technical and environmental requirements for the competing products made from primary raw materials.

A by-product is only a substance or object whose further use is certain [174], i.e., there cannot be a by-product in a landfill, since if the further use would have been certain, it could not have been disposed of. In contrast to "waste" and "by-product" which originate from waste management, the term "residue" stems from process engineering and refers to "the part that is left after the main part has gone or been taken away" [175]. In some MSW landfills also residues can be found, as industrial waste has not always been disposed of in separate landfills. Similar to "residue" also "secondary raw materials" are defined by the Great Soviet Encyclopaedia as "materials and articles which, after complete initial use (wear), may be used repeatedly in production as starting material" [176].

The terms "resource" (reasonable prospects for eventual economic extraction in the foreseeable future) and "reserve" originate from mining economics (current economic extraction possible) and have been introduced into waste management [13]. If current 
economic extraction is possible, the material will be a secondary raw material for a subsequent industrial process, i.e., "anthropogenic reserve" and "secondary raw material" are synonyms. With respect to ELFM, only a small fraction of the excavated materials within NEW-MINE, i.e., the metal fractions from magnetic and eddy current separation or from smelting processes, fall in this category. Some other fractions, e.g., the combustibles, might be classified as "anthropogenic resource" if RDF prices rise significantly above zero. However, the results for the fine fraction do not justify a classification as anthropogenic resource, as no reasonable prospects for their purification exist [71].

In summary, the quantity of resources that can be recovered from MSW landfills can be significant, if valorization options for the inert fraction and the combustibles become feasible. However, quality and "bonitaet" [26] of anthropogenic resources from MSW landfills represent significant challenges for future ELFM projects.

\section{Conclusions}

The NEW-MINE project (2016-2020) was a European research project investigating the entire process chain of ELFM. Within the NEW-MINE project in a first step concentrates of specific materials (e.g., metals, combustibles, inert materials) were produced which might be used as secondary raw materials. In a second step, recycled products (e.g., inorganic polymers, functional glass-ceramics) were produced from these concentrates at the lab scale. However, even if secondary raw materials or recycled products could be produced at a large scale, it remains unclear if they can compete with primary raw materials or products from primary raw materials. Given the ambitions of transition towards a more circular economy, economic incentives are required to make secondary raw materials or recycled products from ELFM competitive in the market.

Author Contributions: Conceptualization, D.V.; methodology, D.V.; investigation, D.V. and L.M.; writing-original draft preparation, D.V.; writing—review and editing, L.M., P.T.J.; visualization, L.M.; supervision, P.T.J., L.M.; project administration, P.T.J., L.M.; funding acquisition, P.T.J. All authors have read and agreed to the published version of the manuscript.

Funding: The NEW-MINE project has received funding from the European Union's EU Framework Program for Research and Innovation Horizon 2020 under Grant Agreement No 721185.

Acknowledgments: The authors thank the entire NEW-MINE team for the fruitful collaboration within the project.

Conflicts of Interest: The authors declare no conflict of interest. The funders had no role in the design of the study; in the collection, analyses, or interpretation of data; in the writing of the manuscript, or in the decision to publish the results.

\section{References}

1. Krook, J.; Svensson, N.; Eklund, M. Landfill mining: A critical review of two decades of research. Waste Manag. 2012, 32, 513-520. [CrossRef] [PubMed]

2. Savage, G.M.; Golueke, C.G.; von Stein, E.L. Landfill mining: Past and present. Biocycle 1993, 34, 58-61.

3. Cobb, C.E.; Ruckstuhl, K. Mining and reclaiming existing sanitary landfills. In Proceedings of the National Waste Processing Conference, Detroit, MI, USA, 17-20 May 1988; pp. 145-151.

4. Rettenberger, G.; Urban-Kiss, S.; Schneider, R.; Göschl, R.; Kremsl, W. Deponierückbau an der deponie burghof in vaihingen/enzhorrheim-Erfahrungen aus einem demonstrationsprojekt. Korresp. Abwasser 1995, 2, 196.

5. Fricke, K.; Münnich, K.; Heußner, C.; Schulte, B.; Wanka, S. Landfill mining-Ein beitrag der abfallwirtschaft für die ressourcensicherung. In Proceedings of the Berliner Recycling-Und Rohstoffkonferenz, Berlin, Germany, 26-27 March 2012; pp. 933-944.

6. Jones, P.T.; Geysen, D.; Tielemans, Y.; van Passel, S.; Pontikes, Y.; Blanpain, B.; Quaghebeur, M.; Hoekstra, N. Enhanced landfill mining in view of multiple resource recovery: A critical review. J. Clean. Prod. 2013, 55, 45-55. [CrossRef]

7. Wolfsberger, T.; Aldrian, A.; Sarc, R.; Hermann, R.; Höllen, D.; Budischowsky, A.; Zöscher, A.; Ragoßnig, A.; Pomberger, R. Landfill mining: Resource potential of Austrian landfills_Evaluation and quality assessment of recovered municipal solid waste by chemical analyses. Waste Manag. Res. 2015, 33, 962-974. [CrossRef] [PubMed] 
8. Wolfsberger, T.; Nispel, J.; Sarc, R.; Aldrian, A.; Hermann, R.; Höllen, D.; Pomberger, A.; Ragossnig, A. Landfill mining: Development of a theoretical method for a preliminary estimate of the raw material potential of landfill sites. Waste Manag. Res. 2015, 33, 671-680. [CrossRef]

9. Hermann, R.; Wolfsberger, T.; Pomberger, R.; Sarc, R. Landfill mining: Developing a comprehensive assessment method. Waste Manag. Res. 2016, 34, 1157-1163. [CrossRef]

10. Wolfsberger, T.; Pinkel, M.; Polansek, S.; Sarc, R.; Pomberger, R. Landfill mining: Development of a cost simulation model. Waste Manag. Res. 2016, 34, 356-367. [CrossRef] [PubMed]

11. Dumont, G.; Pilawski, T.; Dzaomuho-Lenieregue, P.; Hiligsmann, S.; Delvigne, F.; Thonart, P.; Robert, T.; Nguyen, F.; Hermans, T. Gravimetric water distribution assessment from geoelectrical methods (ERT and EMI) in municipal solid waste landfill. Waste Manag. 2016, 55, 129-140. [CrossRef]

12. Wanka, S.; Münnich, K.; Fricke, K. Landfill mining-Wet mechanical treatment of fine MSW with a wet jigger. Waste Manag. 2016, 59, 316-323. [CrossRef]

13. Winterstetter, A.; Laner, D.; Rechberger, H.; Fellner, J. Framework for the evolution of anthropogenic resources: A landfill mining case study-Resource or reserve? Resour. Conserv. Recycl. 2015, 96, 19-30. [CrossRef]

14. Mönkäre, T.; Palmroth, M.; Rintala, J. Characterization of fine fraction mined from two Finnish landfills. Waste Manag. 2016, 47A, 34-39. [CrossRef] [PubMed]

15. Brunner, P. Final Sink: Prerequisite for a cycling society. In Proceedings of the ISWA Beacon 3rd International Conference on Final Sinks, Taipei, China, 23-26 August 2015.

16. Wu, H.; Zuo, J.; Zillante, G.; Wang, J.; Yuan, H. Status quo and future directions of construction and demolition waste research: A critical review. J. Clean. Prod. 2019, 240, 118163. [CrossRef]

17. Silva, R.V.; de Brito, J.; Dhir, R.K. Comparative analysis of existing prediction models on the creep behavior of recycled aggregate concrete. Eng. Struct. 2015, 100, 31-42. [CrossRef]

18. Makarichi, L.; Jutidamrongphan, W.; Techato, K. The evolution of waste-to-energy incineration: A review. Renew. Sustain. Energy Rev. 2018, 91, 812-821. [CrossRef]

19. Sarc, R.; Lorber, K.E. Production, quality and quality assurance of Refuse Derived Fuels (RDFs). Waste Manag. 2013, 33, 1825-1834. [CrossRef] [PubMed]

20. Vollprecht, D.; Riegler, C.; Ahr, F.; Stuhlpfarrer, S.; Wellacher, M. Sequential chemical extraction and mineralogical bonding of metals from Styrian soils. Int. J. Environ. Sci. Technol. 2020, 17, 3663-3676. [CrossRef]

21. European Enhanced Landfill Mining Consortium. Available online: www.eurelco.org (accessed on 16 November 2020).

22. Hernández Parrodi, J.C.; Lucas, H.I.; Gigantino, M.; Sauve, G.; Esguerra, J.L.; Einhäupl, P.; Vollprecht, D.; Pomberger, R.; Friedrich, B.; Van Acker, K.; et al. Integration of resource recovery into current waste management through (enhanced) landfill mining. Detritus 2019, 8, 141-156. [CrossRef]

23. Orlando, L.; Marchesi, E. Georadar as a tool to identify and characterise solid waste dump deposits. J. Appl. Geophys. 2001, 48, 163-174. [CrossRef]

24. Hermozilha, H.; Grangeia, C.; Senos Matias, M. An integrated 3D constant offset GPR and resistivity survey on a sealed landfill Ilhavo, NW Portugal. J. Appl. Geophys. 2010, 70, 58-71. [CrossRef]

25. Porsani, J.; Filho, W.; Elis, V.; Shimeles, F.; Dourado, J.; Moura, H. The use of GPR and VES in delineating a contamination plume in a landfill site: A case study in SE Brazil. J. Appl. Geophys. 2004, 55, 199-209. [CrossRef]

26. Fettweis, G.; Brandstätter, W.; Hruschka, F. Was ist Lagerstättenbonität? Mitt. Osterr. Geol. Ges. 1985, 78, 23-40.

27. Vollprecht, D. Exploration, Mobilization and Fixation of Constituents of Mineral Wastes, Landfills, Contaminated Sites and Waste Waters. Habilitation Thesis, Montanuniversität Leoben, Leoben, Austria, 17 April 2020.

28. Zanetti, M.; Godio, A. Recovery of foundry sands and iron fractions from an industrial waste landfill. Resour. Conserv. Recycl. 2006, 48, 396-411. [CrossRef]

29. Yannah, M.; Martens, K.; van Camp, M.; Walraevens, K. Geophysical exploration of an old dumpsite in the perspective of enhanced landfill mining in Kermt area, Belgium. Bull. Eng. Geol. Environ. 2019, 78, 55-67. [CrossRef]

30. Bobe, C.; Van De Vijver, E.; Van Meirvenne, M. Exploring the potential of electromagnetic surface measurements for the characterization of industrial landfills. In Proceedings of the 4th International Symposium on Enhanced Landfill Mining, Mechelen, Belgium, 5-6 February 2018; pp. 45-50.

31. Wagland, S.; Coulon, F.; Canopoli, L. Developing the case for enhanced landfill mining in the UK. Detritus 2019, 5, 105-110. [CrossRef]

32. Manrique, I.I.; Caterina, D.; Van De Vijver, E.; Dumont, G.; Nguyen, F. Assessment of geophysics as a characterization and monitoring tool in the dynamic landfill management (DLM) context: Opportunities and challenges. In Proceedings of the 17th International Waste Management and Landfill Symposium, Forte Village, Santa Margherita di Pula, Italy, 30 September-4 October 2019.

33. Vollprecht, D.; Bobe, C.; Stiegler, R.; Van de Vijver, E.; Wolfsberger, T.; Küppers, B.; Scholger, R. Relating magnetic properties of municipal solid waste constituents to iron content-Implications for enhanced landfill mining. Detritus 2019, 8, 31-46. [CrossRef]

34. Sandrin, A.; Keiding, J. Integrated geophysical study for landfill mining: A case study in Denmark. In Proceedings of the 82nd EAGE Annual Conference \& Exhibition Workshop Programme, Amsterdam, The Netherlands, 8 December 2020; pp. 1-5. [CrossRef] 
35. Sandrin, A.; Maricak, A.; Heincke, B.; Clausen, R.; Nielsen, L.; Keiding, J. Geophysics for urban mining and the first surveys in Denmark: Rationale, field activity and preliminary results. GEUS Bull. 2020, 44, 5240. [CrossRef]

36. Bobe, C.; Van de Vijver, E.; Keller, J.; Hanssens, D.; Van Meirvenne, M.; De Smedt, P. Probabilistic 1-D inversion of frequencydomain electromagnetic data using a kalman ensemble generator. IEEE Trans. Geosci. Remote Sens. 2020, 58, 3287-3297. [CrossRef]

37. Grana, D.; Liu, M.; Ayani, M. Prediction of $\mathrm{CO}_{2}$ saturation spatial distribution using geostatistical inversion of time-lapse geophysical data. IEEE Trans. Geosci. Remote Sens. 2020. [CrossRef]

38. Hanssens, D.; Waegeman, W.; Declercq, Y.; Dierckx, H.; Verschelde, H.; De Smedt, P. High-resolution surveying with small-loop requency-domain electromagnetic systems: Efficient survey design and adaptive processing. IEEE Geosci. Remote Sens. Mag. 2020. [CrossRef]

39. Bobe, C.; Hanssens, D.; Hermans, T.; Van De Vijver, E. Efficient probabilistic joint inversion of direct current resistivity and small-loop electromagnetic data. Algorithms 2020, 13, 144. [CrossRef]

40. Bobe, C.; Van De Vijver, E. Offset errors in probabilistic inversion of small-loop frequency-domain electromagnetic data: A synthetic study on their influence on magnetic susceptibility estimation. In Proceedings of the International Workshop on Gravity, Electrical \& Magnetic Methods and Their Applications, Xi'an, China, 19-22 May 2019; Society of Exploration Geophysicists: Tulsa, OK, USA, 2019; pp. 312-315. [CrossRef]

41. García López, C.; Küppers, B.; Clausen, A.; Pretz, T. Landfill mining: A case study regarding sampling, processing, and characterization of excavated waste from an Austrian Landfill. Detritus 2018, 2, 29-45. [CrossRef]

42. García López, C.; Ni, A.; Hernández Parrodi, J.C.; Pretz, T.; Raulf, K.; Küppers, B. Characterization of landfill mining material after ballistic separation to evaluate material and energy recovery potential. Detritus 2019, 8, 5-23. [CrossRef]

43. Datta, M.; Somani, M.; Ramana, G.V.; Sreekrishnan, T.R. Feasibility of re-using soil-like material obtained from mining of old MSW dumps as an earth-fill and as compost. Process Saf. Environ. Prot. 2021, 147, 477-487. [CrossRef]

44. Mönkäre, T.; Palmroth, M.R.; Sormunen, K.; Rintala, J. Scaling up the treatment of the fine fraction from landfill mining: Mass balance and cost structure. Waste Manag. 2019, 87, 464-471. [CrossRef]

45. Márquez, A.J.C.; Cassettari Filho, P.C.; Rutkowski, E.W.; de Lima Isaac, R. Landfill mining as a strategic tool towards global sustainable development. J. Clean. Prod. 2019, 226, 1102-1115. [CrossRef]

46. Küppers, B.; Hernández Parrodi, J.C.; García Lopez, C.; Pomberger, R.; Vollprecht, D. Potential of sensor-based sorting in enhanced landfill mining. Detritus 2019, 8, 24-30. [CrossRef]

47. Möllnitz, S.; Küppers, B.; Curtis, A.; Khodier, K.; Sarc, R. Influence of pre-screening on down-stream processing for the production of plastic enriched fractions for recycling from mixed commercial and municipal waste. Waste Manag. 2021, 119, 365-373. [CrossRef] [PubMed]

48. Küppers, B.; Schlögl, S.; Oreski, G.; Pomberger, R.; Vollprecht, D. Influence of surface roughness and surface moisture of plastics on sensor-based sorting in the near infrared range. Waste Manag. Res. 2019, 8, 843-850. [CrossRef] [PubMed]

49. Maier, G.; Pfaff, F.; Bittner, A.; Gruna, R.; Noack, B.; Kruggel-Emden, H.; Hanebeck, U.; Längle, T.; Beyerer, J. Characterizing material flow in sensor-based sorting systems using an instrumented particle. Automatisierungstechnik 2020, 68, 256-264. [CrossRef]

50. Küppers, B.; Schlögl, S.; Friedrich, K.; Lederle, L.; Pichler, C.; Freil, J.; Pomberger, R.; Vollprecht, D. Influence of material alterations and machine impairment on throughput related sensor-based sorting performance. Waste Manag. Res. 2020, 39, 197-198. [CrossRef]

51. Küppers, B.; Seidler, I.; Koinig, I.; Pomberger, R.; Vollprecht, D. Influence of throughput rate and input composition on sensorbased sorting efficiency. Detritus 2020, 9, 59-67. [CrossRef]

52. Curtis, A.; Küppers, B.; Möllnitz, S.; Khodier, K.; Sarc, R. Real time material flow monitoring in mechanical waste processing and the relevance of fluctuations. Waste Manag. 2020, 120, 687-697. [CrossRef]

53. Liebetegger, W. Landfill Mining-Charakterisierung der Fein-Und Heizwertreichen Fraktion. Master's Thesis, Montanuniversität Leoben, Leoben, Austria, 2015.

54. Parrodi, J.C.H.; Höllen, D.; Pomberger, R. Characterization of fine fractions from landfill mining: A review of previous investigations. Detritus 2018, 2, 46-62. [CrossRef]

55. Parrodi, J.C.H.; Höllen, D.; Pomberger, R. Potential and main technological challenges for material and energy recovery from fine fractions of landfill mining: A critical review. Detritus 2018, 3, 19-29. [CrossRef]

56. Hölzle, I. Contaminant patterns in soils from landfill mining. Waste Manag. 2019, 83, 151-160. [CrossRef]

57. Hartemink, A.E. The definition of soil since the early 1800s. Adv. Agron. 2016, 137, 73-126. [CrossRef]

58. Mutafela, R.N.; Marques, M.; Jani, Y.; Kriipsalu, M.; Hogland, W. Physico-chemical characteristics of fine fraction materials from an old crystal glass dumpsite in Sweden. Chem. Ecol. 2019, 35, 877-890. [CrossRef]

59. Somani, M.; Datta, M.; Ramana, G.V.; Sreekrishnan, T.R. Leachate characteristics of aged soil-like material from MSW dumps: Sustainability of landfill mining. J. Hazard. Toxic Radioact. Waste 2019, 23, 04019014. [CrossRef]

60. Mutafela, R.N.; Mantero, J.; Jani, Y.; Thomas, R.; Holm, E.; Hogland, W. Radiometrical and physico-chemical characterisation of contaminated glass waste from a glass dump in Sweden. Chemosphere 2020, 241, 124964. [CrossRef] [PubMed]

61. Mutafela, R.N.; Lopez, E.G.; Dahlin, T.; Kaczala, F.; Marques, M.; Jani, Y.; Hogland, W. Geophysical investigation of glass 'hotspots' in glass dumps as potential secondary raw material sources. Waste Manag. 2020, 106, 213-225. [CrossRef] [PubMed]

62. Pehme, K.M.; Orupõld, K.; Kuusemets, V.; Tamm, O.; Jani, Y.; Tamm, T.; Kriipsalu, M. Field study on the efficiency of a methane degradation layer composed of fine fraction soil from landfill mining. Sustainability 2020, 12, 6209. [CrossRef] 
63. Singh, A.; Chandel, M.K. Effect of ageing on waste characteristics excavated from an Indian dumpsite and its potential valorisation. Process Saf. Environ. Prot. 2020, 134, 24-35. [CrossRef]

64. Mentes, D.; Sebe, E.; Kállay, A.A.; Póliska, C. The firing properties of the biofraction and RDF pellets. Mater. Sci. Eng. 2019, 44, $67-78$.

65. Singh, A.; Chandel, M.K. Physicochemical and FTIR spectroscopic analysis of fine fraction from a municipal solid waste dumpsite for potential reclamation of materials. Waste Manag. Res. 2020, 39, 374-385. [CrossRef] [PubMed]

66. Gunaratne, T.; Krook, J.; Andersson, H.; Eklund, M. Guiding the future research on the valorization of shredder fine fractions: A review of four decades of research. Detritus 2020, 9, 150-164. [CrossRef]

67. Faitli, J.; Nagy, S.; Romenda, R.; Gombkötő, I.; Bokányi, L.; Barna, L. Assessment of a residual municipal solid waste landfill for prospective 'landfill mining'. Waste Manag. Res. 2019, 37, 1229-1239. [CrossRef] [PubMed]

68. Parrodi, J.C.H.; García Lopez, C.; Küppers, B.; Raulf, K.; Vollprecht, D.; Pretz, T.; Pomberger, R. Case study on enhanced landfill mining at Mont-Saint-Guibert landfill in Belgium: Characterization and potential of fine fractions. Detritus 2019, 8, 47-61. [CrossRef]

69. Parrodi, J.C.H.; Raulf, K.; Vollprecht, D.; Pretz, T.; Pomberger, R. Case study on enhanced landfill mining at Mont-Saint-Guibert landfill in Belgium: Mechanical processing of fine fractions for material and energy recovery. Detritus 2019, 8, 62-78. [CrossRef]

70. Parrodi, J.C.H.; Vollprecht, D.; Pomberger, R. Case study on enhanced landfill mining at Mont-Saint-Guibert landfill in Belgium: Physico-chemical characterization and valorization potential of combustibles and inert fractions recovered from fine fractions. Detritus 2020, 10, 44-61. [CrossRef]

71. Vollprecht, D.; Parrodi, J.C.H.; Lucas, H.I.; Pomberger, R. Case study on enhanced landfill mining at Mont-Saint-Guibert landfill in Belgium: Mechanical processing, physico-chemical and mineralogical characterization of fine fractions $<4.5 \mathrm{~mm}$. Detritus 2020, 10, 26-43. [CrossRef]

72. Weber, K.; Quicker, P.; Hanewinkel, J.; Flamme, S. Status of waste-to-energy in Germany, Part I-Waste treatment facilities. Waste Manag. Res. 2020, 38 (Suppl. 1), 23-44. [CrossRef]

73. Viczek, S.; Aldrian, A.; Pomberger, R.; Sarc, R. Determination of the material-recyclable share of SRF during co-processing in the cement industry. Resour. Conserv. Recycl. 2020, 156, 104696. [CrossRef]

74. Austrian Federal Ministry for Climate Action, Environment, Energy, Mobility, Innovation and Technology. Federal Waste Managment Plan 2017. Part 1. Available online: https://www.bmk.gv.at/themen/klima_umwelt/abfall/aws/bundes_awp/ bawp.html (accessed on 24 November 2020).

75. Van Caneghem, J.; Verbinnen, B.; Cornelis, G.; de Wijs, J.; Mulder, R.; Billen, P.; Vandecasteele, C. Immobilization of antimony in waste-to-energy bottom ash by addition of calcium and iron containing additives. Waste Manag. 2016, 54, 162-168. [CrossRef]

76. Winter, B.; Szednyj, I.; Reiseinger, H.; Böhmer, S.; Janhsen, T. Abfallvermeidung und Verwertung: Aschen, Schlacken und Stäube in Österreich. Umweltbundesamt. 2005. Available online: https://www.umweltbundesamt.at/fileadmin/site/publikationen/ rep0003.pdf (accessed on 24 November 2020).

77. Hans van der Sloot Consultancy; DH; ECN. HP Classification of European Incinerator Bottom Ash (IBA). Assessment of Hazardous Properties (HPs) of IBA; Executive Summary of Report Produced for CEWEP. Available online: https: / / www.cewep. eu/guidance-on-classification-of-iba / (accessed on 15 December 2020).

78. Laner, D. Understanding and Evaluating Long-Term Environmental Risks from Landfills. Ph.D. Thesis, Technical Univeristy Vienna, Vienna, Austria, 2011. Available online: https://repositum.tuwien.at/handle/20.500.12708/9360 (accessed on 15 December 2020).

79. Quicker, P. Ein gespenst geht um in Europa. Müll Abfall 2019, 5, 221. Available online: https://muellundabfall.de/.download/ _sid/MFYP-556488-cYzP/147572/mua_20190501.pdf (accessed on 2 December 2020).

80. Zaini, I.N.; Yang, W.; Jönsson, P.G. Steam gasification of solid recovered fuel char derived from landfill waste: A kinetic study. Energy Procedia 2017, 142, 723-729. [CrossRef]

81. Xu, F.; Wang, B.; Yang, D.; Qiao, Y.; Tian, Y. The steam gasification reactivity and kinetics of municipal solid waste chars derived from rapid pyrolysis. Waste Manag. 2018, 80, 64-72. [CrossRef] [PubMed]

82. Lokahita, B.; Samudro, G.; Huboyo, H.S.; Aziz, M.; Takahashi, F. Energy recovery potential from excavating municipal solid waste dumpsite in Indonesia. Energy Procedia 2019, 158, 243-248. [CrossRef]

83. Stasiek, J.; Szkodo, M. Thermochemical conversion of biomass and municipal waste into useful energy using advanced HiTAG/HiTSG technology. Energies 2020, 13, 4218. [CrossRef]

84. Zaini, I.N.; López, C.G.; Pretz, T.; Yang, W.; Jönsson, P.G. Characterization of pyrolysis products of high-ash excavated-waste and its char gasification reactivity and kinetics under a steam atmosphere. Waste Manag. 2019, 97, 149-163. [CrossRef]

85. Liu, H.; Wang, Y.; Zhao, S.; Hu, H.; Cao, C.; Li, A.; Yu, Y.; Yao, H. Review on the current status of the co-combustion technology of organic solid waste (OSW) and coal in China. Energy Fuels 2020, 34, 15448-15487. [CrossRef]

86. Sieradzka, M.; Rajca, P.; Zajemska, M.; Mlonka-Mędrala, A.; Magdziarz, A. Prediction of gaseous products from refuse derived fuel pyrolysis using chemical modelling software Ansys Chemkin Pro. J. Clean. Prod. 2020, 248, 119277. [CrossRef]

87. Al-Salem, S.M.; Yang, Y.; Wang, J.; Leeke, G.A. Pyro-oil and wax recovery from reclaimed plastic waste in a continuous auger pyrolysis reactor. Energies 2020, 13, 2040. [CrossRef]

88. Eke, J.; Bridgwater, A.V.; Onwudili, J.A. Energy recovery by fast pyrolysis of pre-treated trommel fines derived from a UK-based MSW material recycling facility. J. Energy Inst. 2020, 93, 2006-2016. [CrossRef] 
89. Zaini, I.N.; Gomez-Rueda, Y.; García López, C.; Ratnasari, D.K.; Helsen, L.; Pretz, T.; Jönsson, P.G.; Yang, W. Production of H ${ }_{2}$-rich syngas from excavated landfill waste through steam co-gasification with biochar. Energy 2020, 207, 118208. [CrossRef]

90. Sharma, S.; Basu, S.; Shetti, N.P.; Kamali, M.; Walvekar, P.; Aminabhavi, T.M. Waste-to-energy Nexus: A sustainable development. Environ. Pollut. 2020, 267, 115501. [CrossRef]

91. Turk, K. Proizvodnja Amonijaka iz Odpadnih Plinov. Ph.D.Thesis, Maribor University, Maribor, Slovenia, 2020.

92. Gomez-Rueda, Y.; Helsen, L. The role of plasma in syngas tar cracking. Biomass Convers. Biorefinery 2020, 10, 857-871. [CrossRef]

93. Rozzi, E.; Minuto, F.D.; Lanzini, A.; Leone, P. Green synthetic fuels: Renewable routes for the conversion of non-fossil feedstocks into gaseous fuels and their end uses. Energies 2020, 13, 420. [CrossRef]

94. Shahabuddin, M.; Alam, M.T.; Krishna, B.B.; Bhaskar, T.; Perkins, G. A review of producing renewable aviation fuels from the gasification of biomass and residual wastes. Bioresour. Technol. 2020, 312, 123596. [CrossRef] [PubMed]

95. Gomez-Rueda, Y.; Zaini, I.N.; Yang, W.; Helsen, L. Thermal tar cracking enhanced by cold plasma-A study of naphthalene as tar surrogate. Energy Convers. Manag. 2020, 208, 112540. [CrossRef]

96. Du, Y.; Liu, H.; Ren, W. Numerical investigations of a fluidized bed biomass gasifier coupling detailed tar generation and conversion kinetics with particle-scale hydrodynamics. Energy Fuels 2020, 34, 8440-8451. [CrossRef]

97. Lu, G.; Bai, Y.; Ren, L.; Wang, J.; Song, X.; Yu, G. Role of phosphorus (P) additive in the performance of char-supported nickel (Ni) catalyst on tar reforming. Energy Convers. Manag. 2020, 225, 113471. [CrossRef]

98. Fauzi, M.A.; Setyono, P.; Pranolo, S.H. Environmental assessment of a small power plant based on palm kernel shell gasification. AIP Conf. Proc. 2020, 2296, 020038. [CrossRef]

99. Gomez-Rueda, Y.; Zaini, I.N.; Yang, W.; Helsen, L. Seashell waste-derived materials for secondary catalytic tar reduction in municipal solid waste gasification. Biomass Bioenergy 2020, 143, 105828. [CrossRef]

100. Jagodzińska, K.; Zaini, I.N.; Svanberg, R.; Yang, W.; Jönsson, P.G. Pyrolysis of excavated waste from landfill mining: Characterisation of the process products. J. Clean. Prod. 2020, 279, 123541. [CrossRef]

101. Lucas, H.I.; García Lopez, C.; Hernández Parrodi, J.C.; Vollprecht, D.; Raulf, K.; Pomberger, R.; Pretz, T.; Friedrich, B. Quality assessment of nonferrous metals recovered by means of landfill mining: A case study in Belgium. Detritus 2019, 8, 79-90. [CrossRef]

102. Gigantino, M.; Kiwic, D.; Steinfeld, A. Thermochemical energy storage via isothermal carbonation-calcination cycles of MgOstabilized $\mathrm{SrO}$ in the range of 1000-1100 C. Sol. Energy 2019, 188, 720-729. [CrossRef]

103. Pratticò, L.; Bartali, R.; Crema, L.; Sciubba, E. Analysis of radiation propagation inside a hierarchical solar volumetric absorber. Proceedings 2020, 58, 27. [CrossRef]

104. Wild, M.; Steinfeld, A. Modelling of a high-temperature thermochemical storage reactor with radial flow across an annular packed bed using the $\mathrm{CaCO}_{3}-\mathrm{CaO}$ cycle as a model reaction. In Proceedings of the ISES Solar World Congress, Santiago, Chile, 4-9 November 2019. [CrossRef]

105. Morabito, T.; Sau, S.; Tizzoni, A.C.; Spadoni, A.; Capocelli, M.; Corsaro, N.; D’Ottavi, C.; Licoccia, S.; Delise, T. Chemical CSP storage system based on a manganese aluminium spinel. Sol. Energy 2020, 197, 462-471. [CrossRef]

106. André, L.; Abanades, S. Recent advances in thermochemical energy storage via solid-gas reversible reactions at high temperature. Energies 2020, 13, 5859. [CrossRef]

107. Farulla, G.A.; Cellura, M.; Guarino, F.; Ferraro, M. A review of thermochemical energy storage systems for power grid support. Appl. Sci. 2020, 10, 3142. [CrossRef]

108. Gigantino, M.; Sas Brunser, S.; Steinfeld, A. High-temperature thermochemical heat storage via the $\mathrm{CuO} / \mathrm{Cu}_{2} \mathrm{O}$ redox cycle: From material synthesis to packed-bed reactor engineering and cyclic operation. Energy Fuels 2020, 34, 16772-16782. [CrossRef]

109. Dou, X.; Ren, F.; Nguyen, M.Q.; Ahamed, A.; Yin, K.; Chan, W.P.; Chang, V.W.C. Review of MSWI bottom ash utilization from perspectives of collective characterization, treatment and existing application. Renew. Sustain. Energy Rev. 2017, 79, 24-38. [CrossRef]

110. Lucas, H.; Friedrich, B. Thermodynamics of conditioning MSWI bottom ash using SAF for usage in mineral products. In Proceedings of the 6th International Slag Valorisation Symposium, Mechelen, Belgium, 2-4 April 2019; pp. 57-60. Available online: http:/ / www.metallurgie.rwth-aachen.de/new/images/pages/publikationen/thermodynamics_id_7584.pdf (accessed on 27 November 2020).

111. Lucas, H.; Maier, J.; Friedrich, B. The use of submerged arc furnace (SAF) as a robust technology for upcycling waste into standard mineral products for construction industry. Miner. Nebenprodukte Abfälle 2020, 7, 272-287. Available online: https: //www.vivis.de/wp-content/uploads/2020/11/272-287_Friedrich.pdf (accessed on 27 November 2020).

112. Flesoura, G.; Garcia-Banos, B.; Catala-Civera, J.M.; Vleugels, J.; Pontikes, Y. In-situ measurements of high-temperature dielectric properties of municipal solid waste incinerator bottom ash. Ceram. Int. 2019, 45, 18751-18759. [CrossRef]

113. Singh, B.; Zafar, S. Understanding time-temperature characteristics in microwave cladding. Manuf. Lett. 2020, 25, 75-80. [CrossRef]

114. Flesoura, G.; Dilissen, N.; Dimitrakis, G.; Vleugels, J.; Pontikes, Y. A new approach for the vitrification of municipal solid waste incinerator bottom ash by microwave irradiation. J. Clean. Prod. 2020, 284, 124787. [CrossRef]

115. Flesoura, G.; Rabelo Monich, P.; Alarcón, R.M.; Desideri, D.; Bernardo, E.; Vleugels, J.; Pontikes, Y. Porous glass-ceramics made from microwave vitrified municipal solid waste incinerator bottom ash. Constr. Build. Mater. 2020, 270, 121452. [CrossRef] 
116. Ascensão, G.; Marchi, M.; Segata, M.; Faleschini, F.; Pontikes, Y. Reaction kinetics and structural analysis of alkali activated Fe-Si-Ca rich materials. J. Clean. Prod. 2020, 246, 119065. [CrossRef]

117. Kurda, R.; Silva, R.V.; de Brito, J. Incorporation of alkali-activated municipal solid waste incinerator bottom ash in mortar and concrete: A critical review. Materials 2020, 13, 3428. [CrossRef] [PubMed]

118. Ascensão, G.; Beersaerts, G.; Marchi, M.; Segata, M.; Faleschini, F.; Pontikes, Y. Shrinkage and mitigation strategies to improve the dimensional stability of $\mathrm{CaO}-\mathrm{FeO}_{\mathrm{x}}-\mathrm{Al}_{2} \mathrm{O}_{3}-\mathrm{SiO}_{2}$ inorganic polymers. Materials 2019, 12, 3679. [CrossRef] [PubMed]

119. Mast, B.; Cambriani, A.; Douvalis, A.P.; Pontikes, Y.; Schroeyers, W.; Vandoren, B.; Schreurs, S. The effect of high dose rate gamma irradiation on the curing of $\mathrm{CaO}-\mathrm{FeO}_{\mathrm{x}}-\mathrm{SiO}_{2}$ slag based inorganic polymers: Mechanical and microstructural analysis. J. Nucl. Mater. 2020, 539, 152237. [CrossRef]

120. Ascensão, G.; Marchi, M.; Segata, M.; Faleschini, F.; Pontikes, Y. Increasing the dimensional stability of $\mathrm{CaO}^{-}-\mathrm{FeO}_{\mathrm{x}}-\mathrm{Al}_{2} \mathrm{O}_{3}-\mathrm{SiO}_{2}$ alkali-activated materials: On the swelling potential of calcium oxide-rich admixtures. Detritus 2019, 8, 91-100. [CrossRef]

121. Monich, P.R.; Romero, A.R.; Höllen, D.; Bernardo, E. Porous glass-ceramics from alkali activation and sinter-crystallization of mixtures of waste glass and residues from plasma processing of municipal solid waste. J. Clean. Prod. 2018, 188, 871-878. [CrossRef]

122. Bai, C.; Li, H.; Bernardo, E.; Colombo, P. Waste-to-resource preparation of glass-containing foams from geopolymers. Ceram. Int. 2019, 45, 7196-7202. [CrossRef]

123. Romero, A.R.; Salvo, M.; Bernardo, E. Up-cycling of vitrified bottom ash from MSWI into glass-ceramic foams by means of 'inorganic gel casting' and sinter-crystallization. Constr. Build. Mater. 2018, 192, 133-140. [CrossRef]

124. Yatsenko, E.A.; Goltsman, B.M.; Smoliy, V.A.; Yatsenko, L.A. Perspective and experience of use of glass fraction of solid municipal waste in the production of silicate heat-insulating materials. In Proceedings of the 2018 IEEE International Conference of Management of Municipal Waste as an Important Factor of Sustainable Urban Development (WASTE), St. Petersburg, Russia, 4-6 October 2018; pp. 46-48. [CrossRef]

125. Yatsenko, E.A.; Goltsman, B.M.; Ryabova, A.V. Complex protection of pipelines using silicate materials based on local raw materials of the Far East. Mater. Sci. Forum 2019, 945, 46-52. [CrossRef]

126. Yatsenko, E.A.; Goltsman, B.M.; Ryabova, A.V.; Smoliy, V.A. Peculiarities of the use of siliceous raw materials of the Russian Far East in the integrated pipeline protection. In Proceedings of the International Conference on Advanced Functional Materials and Composites (ICAFMC 2018), Barcelona, Spain, 5-7 September 2018; EDP Sciences: Barcelona, Spain, 2018. [CrossRef]

127. Yatsenko, E.A.; Goltsman, B.M.; Smolii, V.A.; Goltsman, N.S.; Yatsenko, L.A. Study on the possibility of applying organic compounds as pore-forming agents for the synthesis of foam glass. Glass Phys. Chem. 2019, 45, 138-142. [CrossRef]

128. Ramteke, D.D.; Hujova, M.; Kraxner, J.; Galusek, D.; Romero, A.R.; Falcone, R.; Bernardo, E. Up-cycling of 'unrecyclable' glasses in glass-based foams by weak alkali-activation, gel casting and low-temperature sintering. J. Clean. Prod. 2021, $278,123985$. [CrossRef]

129. Yatsenko, L.A.; Yatsenko, E.A.; Goltsman, B.M. Development of a mathematical model of the interrelation between the technological parameters of the synthesis and properties of foamed glass materials. Mater. Sci. Forum 2020, 992, 922-928. [CrossRef]

130. Petrella, A.; Spasiano, D.; Race, M.; Rizzi, V.; Cosma, P.; Liuzzi, S.; De Vietro, N. Porous waste glass for lead removal in packed bed column and reuse in cement conglomerates. Materials 2019, 12, 94. [CrossRef] [PubMed]

131. Abdel-Gawwad, H.A.; Mohammed, M.S.; Heikal, M. Ultra-lightweight porous materials fabrication and hazardous leadstabilization through alkali-activation/sintering of different industrial solid wastes. J. Clean. Prod. 2020, 244, 118742. [CrossRef]

132. Bisht, K.; Kabeer, K.S.A.; Ramana, P.V. Gainful utilization of waste glass for production of sulphuric acid resistance concrete. Constr. Build. Mater. 2020, 235, 117486. [CrossRef]

133. Cristelo, N.; Segadães, L.; Coelho, J.; Chaves, B.; Sousa, N.R.; de Lurdes Lopes, M. Recycling municipal solid waste incineration slag and fly ash as precursors in low-range alkaline cements. Waste Manag. 2020, 104, 60-73. [CrossRef]

134. Liu, B.; Yang, Q.W.; Zhang, S.G. Integrated utilization of municipal solid waste incineration fly ash and bottom ash for preparation of foam glass-ceramics. Rare Met. 2019, 38, 914-921. [CrossRef]

135. Romero, A.R.; Tamburini, S.; Taveri, G.; Toušek, J.; Dlouhy, I.; Bernardo, E. Extension of the 'inorganic gel casting' process to the manufacturing of boro-alumino-silicate glass foams. Materials 2018, 11, 2545. [CrossRef]

136. Chen, F.; Zhang, W.; Liu, S. Porous glass-ceramics derived from $\mathrm{MgO}-\mathrm{CuO}-\mathrm{TiO}_{2}-\mathrm{P}_{2} \mathrm{O}_{5}$ glasses with different additions of $\mathrm{Fe} \mathrm{O}_{3}$. Ceram. Int. 2020, 46, 6560-6566. [CrossRef]

137. Korat, L.; Ducman, V. Characterization of fly ash alkali activated foams obtained using sodium perborate monohydrate as a foaming agent at room and elevated temperatures. Front. Mater. 2020, 7, 308. [CrossRef]

138. Teoh, F.; Veksha, A.; Chia, V.W.; Udayanga, W.C.; Mohamed, D.K.B.; Giannis, A.; Lim, T.-T.; Lisak, G. Nickel-based catalysts for steam reforming of naphthalene utilizing gasification slag from municipal solid waste as a support. Fuel $2019,254,115561$. [CrossRef]

139. Xi, C.; Zhou, J.; Zheng, F.; Gao, J.M.; Hu, P.; Li, Y.; Liu, J.L. Conversion of extracted titanium tailing and waste glass to value-added porous glass ceramic with improved performances. J. Environ. Manag. 2020, 261, 110197. [CrossRef]

140. Kraxner, J.; Michalek, M.; Romero, A.R.; Elsayed, H.; Bernardo, E.; Boccaccini, A.R.; Galusek, D. Porous bioactive glass microspheres prepared by flame synthesis process. Mater. Lett. 2019, 256, 126625. [CrossRef]

141. Kumaravel, S.; Alagumurthi, N. Material removal characteristics of $\mathrm{Al}_{-} \mathrm{SiO}_{2}$ composite in WEDM. Epitoanyag J. Silic. Based Compos. Mater. 2020, 72, 20-24. [CrossRef] 
142. Hujova, M.; Rabelo Monich, P.; Sedlacek, J.; Hnatko, M.; Kraxner, J.; Galusek, D.; Bernardo, E. Glass-ceramic foams from alkali-activated vitrified bottom ash and waste glasses. Appl. Sci. 2020, 10, 5714. [CrossRef]

143. Rabelo Monich, P.; Dogrul, F.; Lucas, H.; Friedrich, B.; Bernardo, E. Strong porous glass-ceramics from alkali activation and sinter crystallization of vitrified MSWI bottom ash. Detritus 2019, 8, 101-108. [CrossRef]

144. Rabelo Monich, P.; Vollprecht, D.; Bernardo, E. Dense glass-ceramics by fast sinter-crystallization of mixtures of waste-derived glasses. Int. J. Appl. Ceram. Technol. 2020, 17, 55-63. [CrossRef]

145. Li, B.; Guo, Y.; Fang, J. Effect of crystallization temperature on glass-ceramics derived from tailings waste. J. Alloy. Compd. 2020, 838, 155503. [CrossRef]

146. Rabelo Monich, P.; Desideri, D.; Bernardo, E. Low temperature upcycling of vitreous byproduct of the MSW plasma processing into multifunctional porous glass-ceramics. Adv. Appl. Ceram. 2019, 118, 366-371. [CrossRef]

147. Salman, M.M.; Nhabih, H.T. Assessment of the partial and total replacement of feldspar by waste glass on porcelain properties. J. Ceram. Process. Res. 2020, 21, 371-377. [CrossRef]

148. Salman, M.M.; Radhi, N.S.; Sabr, O.H.; Nhabih, H.T. Utilization of diverse cheap materials as pore generating agent to manufacture low-cost porous ceramic. Cerâmica 2020, 66, 179-185. [CrossRef]

149. Rabelo Monich, P.; Romero, A.R.; Desideri, D.; Bernardo, E. Waste-derived glass-ceramics fired in nitrogen: Stabilization and functionalization. Constr. Build. Mater. 2020, 232, 117265. [CrossRef]

150. Rincón Romero, A.; Desideri, D.; Boccaccini, A.R.; Bernardo, E. Up-cycling of iron-rich inorganic waste in functional glass-ceramics. Minerals 2020, 10, 959. [CrossRef]

151. Zhang, Z.; Wang, J.; Liu, L.; Ma, J.; Shen, B. Preparation of additive-free glass-ceramics from MSW incineration bottom ash and coal fly ash. Constr. Build. Mater. 2020, 254, 119345. [CrossRef]

152. Sauve, G.; Van Acker, K. The environmental impacts of municipal solid waste landfills in Europe: A life cycle assessment of proper reference cases to support decision making. J. Environ. Manag. 2020, 261, 110216. [CrossRef]

153. Chabok, M.; Asakereh, A.; Bahrami, H.; Jaafarzadeh, N.O. Selection of MSW landfill site by fuzzy-AHP approach combined with GIS: Case study in Ahvaz, Iran. Environ. Monit. Assess. 2020, 192, 1-15. [CrossRef]

154. Manyoma-Velásquez, P.C.; Vidal-Holguín, C.J.; Torres-Lozada, P. Methodology for locating regional landfills using multi-criteria decision analysis techniques. Cogent Eng. 2020, 7, 1776451. [CrossRef]

155. Pokhrel, P.; Lin, S.L.; Tsai, C.T. Environmental and economic performance analysis of recycling waste printed circuit boards using life cycle assessment. J. Environ. Manag. 2020, 276, 111276. [CrossRef]

156. Cho, H.H.; Strezov, V. A comparative review on the environmental impacts of combustion-based electricity generation technologies. Energy Fuels 2020, 34, 10486-10502. [CrossRef]

157. Vaverková, M.D.; Adamcová, D.; Winkler, J.; Koda, E.; Petrželová, L.; Maxianová, A. Alternative method of composting on a reclaimed municipal waste landfill in accordance with the circular economy: Benefits and risks. Sci. Total Environ. 2020, 723, 137971. [CrossRef] [PubMed]

158. Tan, W.; Wang, S.; Liu, N.; Xi, B. Tracing bacterial and fungal necromass dynamics of municipal sludge in landfill bioreactors using biomarker amino sugars. Sci. Total Environ. 2020, 741, 140513. [CrossRef]

159. Efremenko, E.; Senko, O.; Stepanov, N.; Mareev, N.; Volikov, A.; Perminova, I. Suppression of methane generation during methanogenesis by chemically modified humic compounds. Antioxidants 2020, 9, 1140. [CrossRef]

160. Manasaki, V.; Palogos, I.; Chourdakis, I.; Tsafantakis, K.; Gikas, P. Techno-economic assessment of landfill gas (LFG) to electric energy: Selection of the optimal technology through field-study and model simulation. Chemosphere 2020, 41, 128688. [CrossRef] [PubMed]

161. Raksasat, R.; Lim, J.W.; Kiatkittipong, W.; Kiatkittipong, K.; Ho, Y.C.; Lam, M.K.; Font-Palma, C.; Zaid, H.F.M.; Cheng, C.K. A review of organic waste enrichment for inducing palatability of black soldier fly larvae: Wastes to valuable resources. Environ. Pollut. 2020, 267, 115488. [CrossRef] [PubMed]

162. Sauve, G.; Van Acker, K. To mine or not to mine: A review of the effects of waste composition, time and long-term impacts of landfills in the decision making for ELFM. In Proceedings of the 4th International Symposium on Enhanced Landfill Mining, Mechelen, Belgium, 5-6 February 2018; pp. 379-385.

163. Esguerra, J.L.; Krook, J.; Svensson, N.; Van Passel, S. Assessing the economic potential of landfill mining: Review and recommendations. Detritus 2019, 8, 125-140. [CrossRef]

164. Esguerra, J.L.; Svensson, N.; Krook, J.; Van Passel, S.; Van Acker, K. The economic and environmental performance of a landfill mining project from the viewpoint of an industrial landfill owner. In Proceedings of the 4th International Symposium on Enhanced Landfill Mining, Mechelen, Belgium, 5-6 February 2018; pp. 389-395.

165. Laner, D.; Esguerra, J.L.; Krook, J.; Horttanainen, M.; Kriipsalu, M.; Rosendal, R.M.; Stanisavljević, N. Systematic assessment of critical factors for the economic performance of landfill mining in Europe: What drives the economy of landfill mining? Waste Manag. 2019, 95, 674-686. [CrossRef]

166. Vaverková, M.D. Landfill impacts on the environment. Geosciences 2019, 9, 431. [CrossRef]

167. Sabour, M.R.; Alam, E.; Hatami, A.M. Environmental and economic assessment of enhanced landfill mining in Tehran. Environ. Sci. Pollut. Res. 2020, 27, 34469-34483. [CrossRef] [PubMed]

168. Martinovsky, J. Repräsentative Demokratie in Österreich am Beispiel der Volksabstimmung über das Kernkraftwerk Zwentendorf. Diploma Thesis, Vienna University, Wien, Austria, 2012. [CrossRef] 
169. Einhäupl, P.; Krook, J.; Svensson, N.; Van Acker, K.; Van Passel, S. Enhanced landfill mining at the Remo Site: Assessing stakeholders' perspectives for implementation. In Proceedings of the 4th International Symposium on Enhanced Landfill Mining, Mechelen, Belgium, 5-6 February 2018; pp. 367-377.

170. Einhäupl, P.; Krook, J.; Svensson, N.; Van Acker, K.; Van Passel, S. Eliciting stakeholder needs-An anticipatory approach assessing enhanced landfill mining. Waste Manag. 2019, 98, 113-125. [CrossRef]

171. Pecorini, I.; Iannelli, R. Characterization of excavated waste of different ages in view of multiple resource recovery in landfill mining. Sustainability 2020, 12, 1780. [CrossRef]

172. Einhäupl, P.; Van Acker, K.; Svensson, N.; Van Passel, S. Developing stakeholder archetypes for enhanced landfill mining. Detritus 2019, 8, 109-124. [CrossRef]

173. Müller, A. Baustoffrecycling; Springer: Wiesbaden, Germany, 2018. [CrossRef]

174. Directive 2008/98/EC of the European Parliament and of the Council of 19 November 2008 on Waste and Repealing Certain Directives. Available online: http:/ / data.europa.eu/eli/dir/2008/98/oj (accessed on 24 November 2020).

175. Cambridge Dictionary: Residue; Cambridge University Press: Cambridge, UK; Available online: https://dictionary.cambridge.org/ de/worterbuch/englisch/residue (accessed on 15 March 2020).

176. Prochorow, A. (Ed.) The Great Soviet Encyclopedia. 1970-1979; Available online: https:/ / encyclopedia2.thefreedictionary.com/ Secondary+Raw+Material (accessed on 17 November 2020). 